TEKNIK, 42 (3), 2021, 309-315

\title{
Analysis of Fine Glass Waste Addition as a Filler Material for Sand Substitution on the Properties of Mortar Products
}

\author{
Suharto $^{1}$, Muhammad Amin $^{1}$, Muhammad Al Muttaqii ${ }^{2 *}$, Roniyus Marjunus ${ }^{3}$, Nuzullia Fitri ${ }^{3}$, Suhartono $^{4}$ \\ ${ }^{1}$ Balai Penelitian Teknologi Mineral, Badan Riset dan Inovasi Nasional (BRIN), \\ Jl. Ir. Sutami KM 15 Lampung Selatan, Indonesia 35361 \\ ${ }^{2}$ Pusat Riset Kimia, Badan Riset dan Inovasi Nasional (BRIN), \\ Jl. Puspitek serpong Gd.452, Kota Tangerang Selatan, Banten, Indonesia 15314 \\ ${ }^{3}$ Jurusan Fisika, Universitas Lampung, \\ Jl. Prof. Dr. Sumantri Brojonegor No.1 Lampung, Indonesia 35145 \\ ${ }^{4}$ Jurusan Teknik Kimia, Fakultas Teknik, Universitas Jenderal Achmad Yani, \\ Jl. Terusan Jenderal Sudirman, Cimahi, Indonesia 40533
}

\begin{abstract}
Inorganic glass waste can replace sand in mortar production due to its $\mathrm{SiO}_{2}$ content being greater than 70\%. This study aims to analyze the increase in mortal product agility due to the substitution of sand and reducing environmental pollution. The fine glass waste used is restrained on 80 and 120 mesh sieves. The fine glass waste substitution variations are 0,10,20,30,40, and 50\% of the sand weight. The results show that fine glass waste could be used as a material for sand substitution because of the content of SiO2 of 73.8\%. The results from XRD indicate that the phase of fine waste glass is amorphous. The mortar was printed with a $5 \times 5 \times 5 \mathrm{~cm}$ cube mold, and it was soaked for 7, 14, and 21 days. Based on the results, the compressive strength with a high value of $13.58 \mathrm{MPa}$ at $20 \%$ fine glass waste substitution and 120 mesh. The density of $2.8 \pm 0.8 \mathrm{~g} / \mathrm{cm}^{3}$, porosity $4.40 \pm 0.001 \%$, and absorption $2.83 \pm 0,0009 \%$. The compressive strengths, density, porosity, absorption, XRF and XRD characterization were evaluated. The results showed that the $\mathrm{SiO}_{2}$ compound in waste glass with the right composition of $20 \%$ could significantly increase the compressive strength. Phase formation of Calcite $\left(\mathrm{CaCO}_{3}\right)$, Quartz $\left(\mathrm{SiO}_{2}\right)$, and Portlandite $\left(\mathrm{Ca}(\mathrm{OH})_{2}\right)$ was formed from the results of XRF characterization
\end{abstract}

Keywords: fine glass waste; sand; filler; mortar

\section{Introduction}

Mortar is a mixture of cement, sand, and water. Sand is the most widely used as a raw material in mortar production, approximately $60-70 \%$ of the total. The more sand as aggregate, the more the amount needed, so the availability of sand in nature decreases. It is necessary to research alternative raw materials to replace the sand. One of the wastes that can be used as a substitute for sand in mortar is glass waste. Glass waste is an abundant inorganic waste, reaching 0.7 million tons per year in Indonesia. Most of it comes from bottles, building glass waste, and kitchen glass. The main compound contains more than $70 \% \mathrm{SiO}_{2}$. Glass waste can be used because it contains $\mathrm{SiO}_{2}$, available in large quantities, and reduces environmental pollution.

${ }^{*)}$ Corresponding author

E-mail: almuttaqiimuhammad@gmail.com
(Ramadani, 2018; Choi et al., 2018).

Several studies have carried out the addition of glass waste for mortar manufacture. For example, Choi et al. (2018) reported using glass waste to substitute sand in mortar. The glass waste used has passed a $5 \mathrm{~mm}$ sieve and a density of $3.0 \mathrm{~g} / \mathrm{cm}^{3}$. The results show that the burning loss decreases when the substitution ratio of waste glass increases. However, the expansion of mortar by Alkali-Silica Reaction (ASR) gradually increases with the increasing substitution ratio of waste glass. However, waste glass is suitable for fine aggregate in mortar specimens (Choi et al., 2018).

Furthermore, another study by Bentchikou et al. (2017) used fine glass waste with variations of $10 \%$, $25 \%, 35 \%, 50 \%, 75 \%$, and $100 \%$ with immersion times of 7,28 , and 90 days. The glass waste used has a fineness level of $3.83 \mathrm{~cm}^{2} / \mathrm{gram}$ and a density of 2.49 $\mathrm{g} / \mathrm{cm}^{3}$. The substitution variation of $35 \%$ and $10 \%$ on day 28 was optimal in terms of the mechanical strength of the mortar. 


\section{TEKNIK, 42 (3), 2021, 310}

Table 1. The composition of production mortar

\begin{tabular}{ccccc}
\hline $\begin{array}{c}\text { Glass } \\
\text { substitution } \\
(\text { wt.\%) }\end{array}$ & $\begin{array}{c}\text { Cement Sand } \\
(\mathbf{g})\end{array}$ & $\begin{array}{c}\text { Glass waste } \\
\text { (g) }\end{array}$ & $\begin{array}{c}\text { Wate } \\
\text { substitution } \\
\text { (g) }\end{array}$ & \\
\hline 0 & 500 & 2.500 & 0 & 300 \\
10 & 500 & 2.250 & 250 & 300 \\
20 & 500 & 2.000 & 500 & 300 \\
30 & 500 & 1.750 & 750 & 300 \\
40 & 500 & 1.500 & 1.000 & 300 \\
50 & 500 & 1.250 & 1.250 & 300 \\
\hline
\end{tabular}

When fine glass waste is used as a filler with a smaller particle size and combined with the pozzolanic reaction, it is possible to get a better mortar. Furthermore, adding $10 \%$ and $20 \%$ substituted fine glass waste used in mortar as a substitute for natural aggregate and cement, respectively, has good compressive strength. Therefore, the use of glass waste can reduce the use of cement, which causes environmental impacts (Letelier et al., 2019).

\section{Materials and Methods \\ 2.1 Materials}

The materials used are fine glass waste, sand, PCC cement (Portland Composite Cement), and water. The raw material in mortar production, such as cement, sand, fine glass waste, and water, with the composition, were presented in Table 1 .

\subsection{Mortar Preparation and Production}

The preparation of this study followed the research of Amin and Suharto, 2017. First, the glass waste was pulverized using Ball Milling for five $\mathrm{h}$ to obtain fine glass waste. Then, the fine glass waste was sieved using 60, 80, 100, and 120 mesh sieves (SNI. 031968-1990). Next, fine glass waste, sand, cement, and water are stirred in a mixer for 20-30 min until it becomes a cement mixture. Furthermore, it was molded with a $5 \times 5 \times 5 \mathrm{~cm}$ cube mold until it became a mortar. The mortar dried at room temperature for $24 \mathrm{~h}$. Finally, the mortar was removed from the mold. Mortar soaked in water for 7, 14, and 21 days (SNI. 03-6825-2002).

\subsection{Characterization of mortar}

Mortars were characterized by X-Ray Diffraction (XRD), X-Ray Fluorescence (XRF), and physical tests such as porosity, absorption, density, and compressive strength .

\section{Results and Discussion}

The results of X-Ray Fluorescence (XRF) characterization on the sand and fine glass waste can be seen in Table 2. Table 2 shows that sand has the highest $\mathrm{SiO}_{2}$ compound content of $64.8 \%$, while fine glass waste is $73.8 \%$. Glass waste can be used as a substitute for
Table 2. The results of XRF characterization on the sand and fine glass waste

\begin{tabular}{ccc}
\hline Compound & $\begin{array}{c}\text { Sand } \\
(\text { wt.\%) }\end{array}$ & $\begin{array}{c}\text { Fine glass waste } \\
\text { (wt.\%) }\end{array}$ \\
\hline $\mathrm{SiO}_{2}$ & 64.8 & 73.8 \\
$\mathrm{CaO}$ & 6.2 & 16.8 \\
$\mathrm{Fe}_{2} \mathrm{O}_{3}$ & 11.0 & 3.4 \\
$\mathrm{MgO}$ & 0.2 & 2.3 \\
$\mathrm{Al}_{2} \mathrm{O}_{3}$ & 7.4 & 2.0 \\
$\mathrm{P}_{2} \mathrm{O}_{5}$ & 1.3 & 1.0 \\
$\mathrm{~K}_{2} \mathrm{O}$ & 1.7 & 0.3 \\
$\mathrm{TiO}_{2}$ & 4.4 & 0.2 \\
$\mathrm{MnO}$ & 0.2 & 0.1 \\
\hline
\end{tabular}

sand because it contains a lot of $\mathrm{SiO}_{2}$ compounds. $\mathrm{SiO}_{2}$ compounds can increase the compressive strength significantly (Walczak et al., 2015). In addition, the use of glass waste as a substitute for sand can reduce unused glass waste (Rahim et al., 2015).

The XRF results obtained for the waste glass samples are comparable with a standard pozzolana in which $\left(\mathrm{SiO}_{2}+\mathrm{Al}_{2} \mathrm{O}_{3}+\mathrm{Fe}_{2} \mathrm{O}_{3}\right)$ 's minimum requirement is $70 \%$. Therefore, glass powder samples can be considered in par to pozzolanic behavior in cement systems.

The diffractogram of sand and fine glass waste is shown in Figure 1. Figure 1 shows the characteristics of the sand are Quartz (Joni et al., 2019). The phase formed in the XRD characterization results is in accordance with the XRF results, containing many $\mathrm{SiO}_{2}$ elements.

Figure 1 shows that the characteristics of fine glass waste are not structured (amorphous). This is indicated by the absence of diffraction peaks formed (Olofinnade et al., 2015). The amorphous formation is caused when $\mathrm{SiO}_{2}$ glass is made by heating at high temperatures.

The results on the physical properties of sand can be seen in Table 3. Based on Table 3. it can be seen that the water content test determines the difference in weight between the materials before and after drying. The water content results are $(1 \pm 0.002) \%$. Based on ASTM D-2216 (1999), the sand moisture content test qualified because it has a moisture content of less than $10 \%$. If it is more than $10 \%$, it will cause a decrease in the mechanical strength of the mortar because the sand will absorb too much water.

The table also shows that mud content testing to determine the percentage of silt contained in the sand. The silt content test in the sand is obtained at $(4.5 \pm 0.001) \%$. This sand qualified, which is less than $5 \%$ based on SNI S-04-1989-F. Excessive mud content will interfere with the adhesion between the surface of 


\section{TEKNIK, 42 (3), 2021, 311}

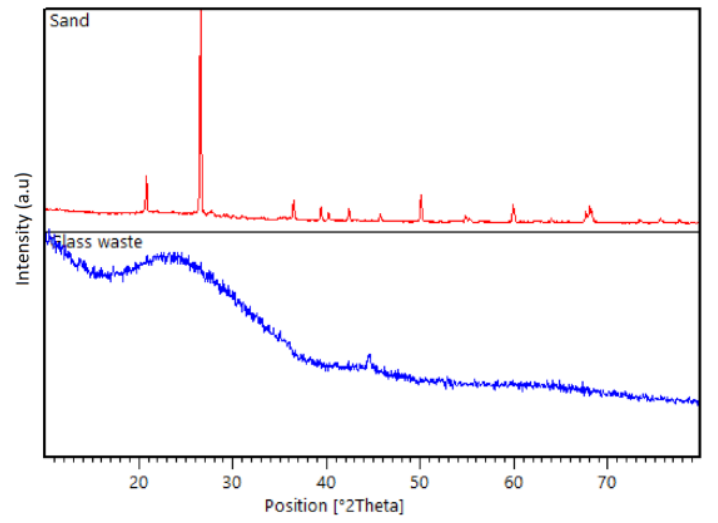

Figure 1. The diffractogram of sand and fine glass waste

the sand particles and cement paste, thereby reducing the compressive strength of the mortar.

Based on the gradation test of the sand obtained size of $2.37 \pm 0.01$. The results requirements as fine sand based on SNI. 03-1968-1990, because it has a fine particle modulus between 2.20 to 2.60 . In general, sand is grouped into three levels of fineness, fine sand of 2.20-2.60, medium sand of 2.60-2.90, and coarse sand of 2.90-2.60. Overall, the sand material used in this study has requirements as a substitute for sand in the manufacture of mortar.

\subsection{Mortar Physical Test Results on the Composition of Refined Glass Waste}

\subsubsection{Compressive Strength Results}

Compressive strength testing aims to determine the magnitude of the load per unit area. However, it causes the test object to crumble when loaded with a certain compressive force by the machine. The manufacture of this mortar uses fine glass with particle sizes of 80 and 120 mesh as a substitute for sand with the mortar treatment soaked for 7, 14, and 21 days. Then the compressive strength test is carried out using the UTM machine. Based on the test results, the compressive strength of mortar with variations in substitution of fine glass waste soaked for 7, 14, and 21 days can be seen in Figures 2.

The lowest compressive strength results were obtained from the substitution of $20 \%$ fine glass waste by immersion for seven (7) days on an 80 mesh molecular sieve. The compressive strength of mortar is 8.98 MPa. The optimum compressive strength was obtained by substituting $20 \%$ fine glass waste by immersion for 21 days on a 120 mesh molecular sieve. The compressive strength of mortar is $13.58 \mathrm{MPa}$. This shows that the longer the mortar is soaked, the better the compressive strength obtained. Due to the C-S-H reaction (Calcium Silicate Hydrate) will be perfectly hydrated in the air (Walczak et al., 2015).
Table 3. Physical properties of sand

\begin{tabular}{lccc}
\hline Test & Result & Standard & Information \\
\hline Water & $(1 \pm 0.002) \%$ & $\leq 10 \%$ & Qualify \\
content & & & (ASTM \\
& & & D-2216) \\
Mud level & $(4.5 \pm 0.001) \%$ & $\leq 5 \%$ & $\begin{array}{c}\text { Qualify } \\
\text { (SNI } \\
\end{array}$ \\
& & & S-04-1989-F) \\
Gradation & $2.37 \pm 0.01$ & $2.20-2.60$ & Qualify \\
& & & (SNI \\
& & & $03-1968-1990)$ \\
\hline
\end{tabular}

Refined glass waste as a substitute for sand can affect the compressive strength of mortar. This is due to $\mathrm{SiO}_{2}$ content in fine glass waste functions as a filler in making mortar and has a maximum percentage of sand substitution. However, the production of mortar using raw materials consisting of sand, cement, and water still causes the air voids to be filled with water during the immersion period. This air cavity is covered with fine glass waste to increase the compressive strength of the mortar (Jesus et al., 2019).

However, the substitution of fine glass waste with the right substitution can increase the compressive strength at a maximum substitution variation of $20 \%$. This happens because the addition of fine glass has a maximum limit. The addition of excessive fine glass waste will decrease the compressive strength value and the cement's decreased ability to bind the materials contained in the mortar because it is excessive. The $\mathrm{SiO}_{2}$ content produced by the substitution of fine glass exceeds $20 \%$. When substitution variations of 30 to $50 \%$ were done, the $\mathrm{SiO}_{2}$ content increased. The $\mathrm{SiO}_{2}$ content in the mortar decreases the compressive strength. Compressive strength decrease was caused by the mortar having excessive shafts or pores. Substitutions of up to $20 \%$ have similar results to traditional mortal mixtures.

Meanwhile, the substitution of $30 \%$ causes a dilution effect that negatively impacts the insufficient amount of $\mathrm{CaCO}_{3}$ that remains to react with silica from glass waste. This causes the mechanical properties to decrease proportionally. (Hambali et al., 2013).

The fine glass particle size of 120 mesh has a higher compressive strength value than the particle size of 80 mesh. This is because smaller particle sizes can fill the pores of the sand more. Therefore, the mortar will become more compact, and the compressive strength value will be higher than the larger particle size.

\subsubsection{Density Results}

Density testing aims to determine the ratio between the density of a material with the density of water with the same volume. Figure 3 shows the mortar density with variations in substitution of fine glass waste 


\section{TEKNIK, 42 (3), 2021, 312}

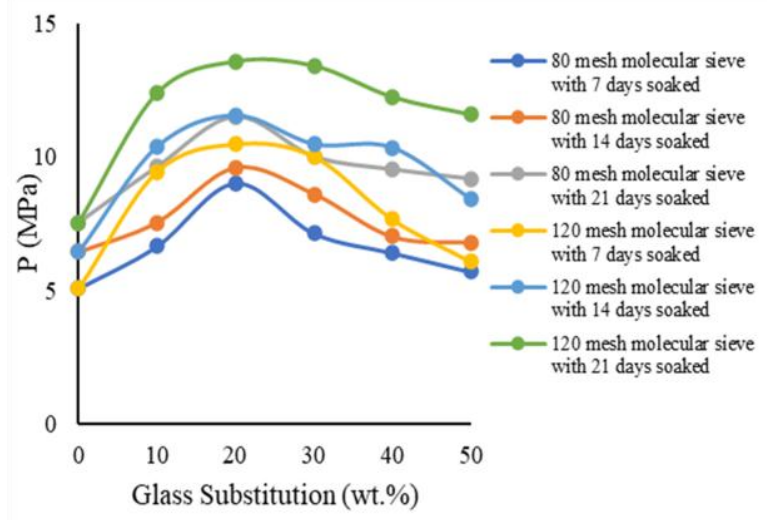

Figure 2. The compressive strength of mortar with variations in substitution of fine glass waste soaked for 7,14 , and 21 days

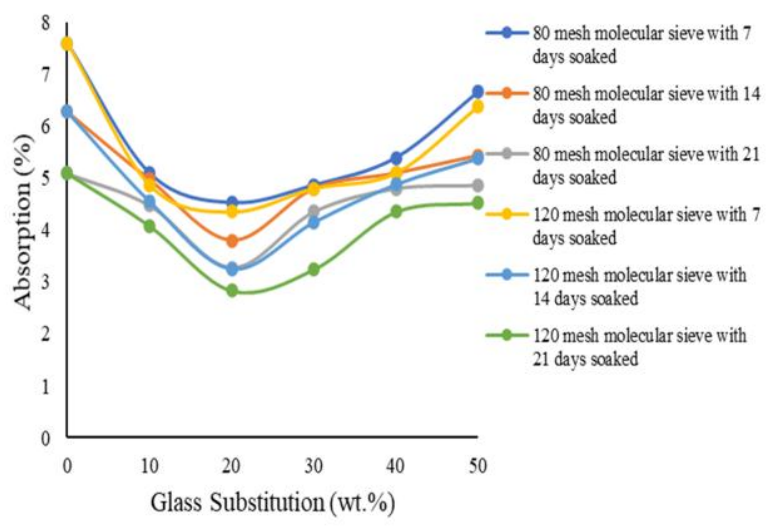

Figure 4. The absorption of mortar with variations in substitution of fine glass waste soaked for 7, 14, and 21 days

soaked for 7,14 , and 21 days. The optimum density was obtained by substituting $20 \%$ fine glass waste by immersion for 21 days on a 120 mesh molecular sieve. The density of mortar is $2.8 \pm 0.8 \mathrm{~g} / \mathrm{cm}^{3}$.

Based on Figure 3, the finer the glass waste used in the mortar mixture, the higher the density produced. This is because sand, cement, fine glass waste, and water are solid, so they are perfectly hydrated with water (Tamanna et al., 2013). The higher the compressive strength of mortar caused, the higher the density value (Jesus et al., 2019). For example, the density value of mortar soaked for 21 days was higher than that of mortar soaked for 7 and 14 days, with a 20\% fine glass waste substitution variation. Furthermore, using a particle size of 120 mesh, the obtained density is higher than 80 mesh. This is because the smaller the particle size, the higher the density level, and the smaller the pores.

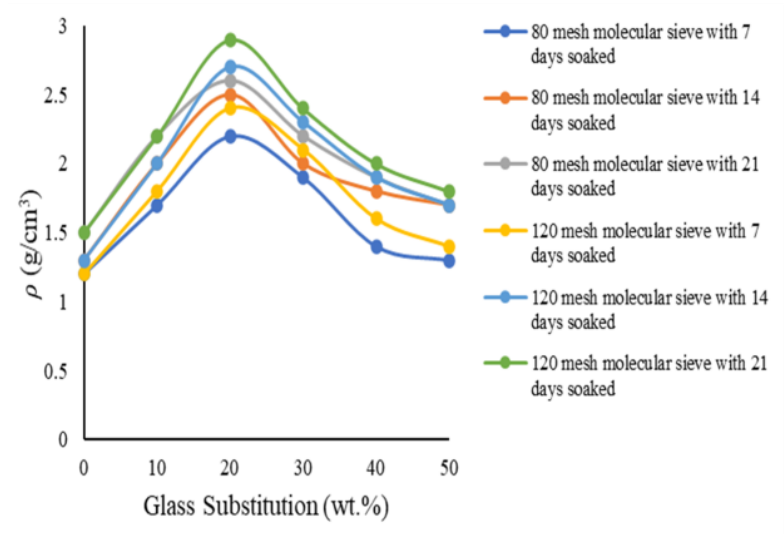

Figure 3. The density of mortar with variations in substitution of fine glass waste soaked for 7, 14, and 21 days

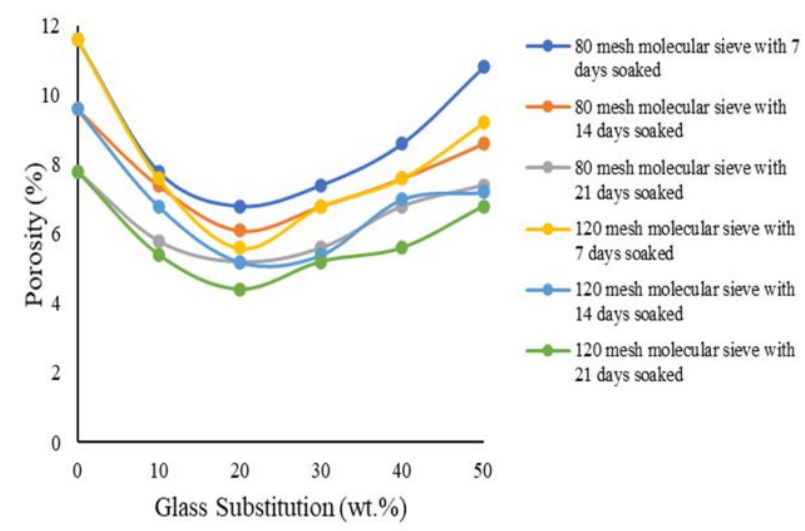

Figure 5. The porosity of mortar with variations in substitution of fine glass waste soaked for 7, 14, and 21 days

Glass powder particle size and morphology affect the workability of mortar. Finer glass powder contributes to increased workability by reducing friction between the particles.

\subsubsection{Absorption Results}

Absorption is a large percentage of air absorption due to air spaces in the mortar. Figure 4 shows the absorption of mortar with variations in the substitution of fine glass waste soaked for 7, 14, and 21 days. The optimum absorption was obtained from the substitution of $20 \%$ fine glass waste by immersion for 21 days on a 120-mesh molecular sieve. The absorption is $2.83 \pm 0.0009 \%$.

High absorption causes low compressive strength and density, and vice versa. This is because the pores in the mortar are covered by fine glass. The absorption 


\section{TEKNIK, 42 (3), 2021, 313}

Table 4. The results of XRF characterization of mortar

\begin{tabular}{ccccc}
\hline & \multicolumn{4}{c}{ Glass substitution (wt.\%) } \\
\hline Compounds & $\begin{array}{c}\text { 80 mesh } \\
\text { molecular } \\
\text { sieve with } \\
\text { 20\% }\end{array}$ & $\begin{array}{c}\text { 80 mesh } \\
\text { molecular } \\
\text { sieve with } \\
\text { 50\% }\end{array}$ & $\begin{array}{c}\text { 120 mesh } \\
\text { molecular } \\
\text { sieve with } \\
\mathbf{2 0 \%}\end{array}$ & $\begin{array}{c}\text { 120 mesh } \\
\text { molecular } \\
\text { sieve with } \\
\text { 50\% }\end{array}$ \\
\hline $\mathrm{CaO}$ & 68.3 & 62.1 & 55.2 & 42.3 \\
$\mathrm{SiO}_{2}$ & 19.8 & 23.4 & 28.7 & 37.4 \\
$\mathrm{Fe}_{2} \mathrm{O}_{3}$ & 6.0 & 8.0 & 8.9 & 11.7 \\
$\mathrm{Al}_{2} \mathrm{O}_{3}$ & 2.8 & 2.5 & 2.5 & 2.4 \\
$\mathrm{TiO}_{2}$ & 1.5 & 2.1 & 2.8 & 3.8 \\
$\mathrm{SO}_{3}$ & 0.6 & 0.5 & 0.4 & 0.3 \\
$\mathrm{MgO}$ & 0.6 & 0.8 & 0.8 & 1.2 \\
$\mathrm{~K}_{2} \mathrm{O}$ & 0.2 & 0.2 & 0.3 & 0.3 \\
$\mathrm{SrO}$ & 0.1 & 0.1 & 0 & 0.1 \\
$\mathrm{MnO}$ & 0 & 0.1 & 0.1 & 0.1 \\
\hline
\end{tabular}

value increases when the percentage of addition of fine glass substitution in the sand ranges from 30-50.

The absorption value on the 120 mesh molecular sieve is better than the 80 mesh size. This is because finer particle size will be easier to cover the air cavities in the mortar. Therefore, the mortar density can be increased. The mortar density can reduce the absorption value so that the density value can increase (Jesus et al., 2019).

\subsubsection{Porosity Results}

Porosity is the percentage of the pores' size in the mortar. Figure 5 shows the porosity of mortar with variations in substitution of fine glass waste soaked for 7,14 , and 21 days. The optimum porosity was obtained by substituting $20 \%$ fine glass waste by immersion for 21 days on a 120 mesh molecular sieve. The porosity is $4.4 \pm 0.001 \%$.

The fine glass waste serves as a filler and can reduce the porosity because the pores in the mortar are filled. The porosity value of 30 to $50 \%$ is still better than without fine glass waste addition or $0 \%$. The decrease in the porosity value is caused by too much $\mathrm{SiO}_{2}$ content in the glass and sand, causing the cement's ability to bond sand and glass to decrease. The higher the porosity values, the lower the compressive strength and density values. However, it is directly proportional to the magnitude of the absorption value (Jesus et al., 2019).

\subsubsection{X-Ray Fluorescence (XRF) Characterization} Results of Mortar

The results of XRF characterization on mortar can be seen in Table 4. XRF results show that mortar has the highest compound content of $\mathrm{CaO}$ at 80 mesh molecular sieve with a $20 \%$ substitution variation of $68.3 \%$. In contrast, the $50 \%$ substitution variation decreases to $62.1 \%$, with a mesh molecular sieve of 120

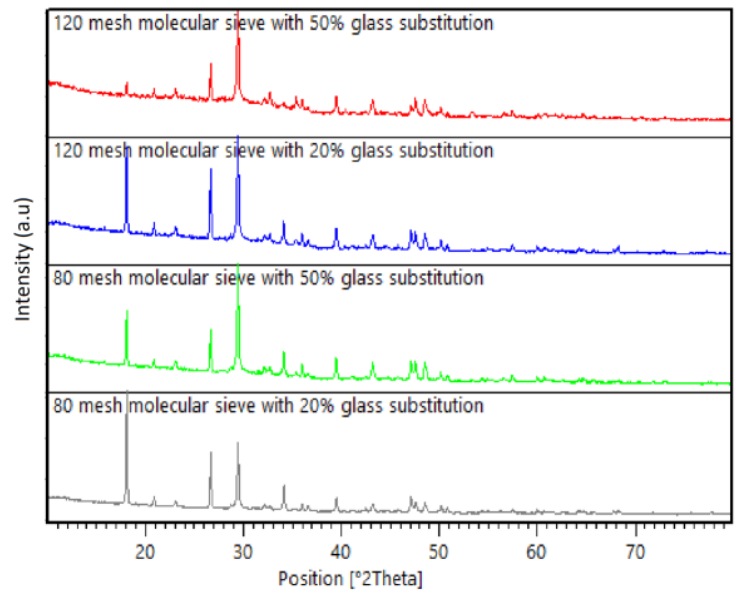

Figure 6. The diffractogram of mortar with 80 and 120 molecular sieves with 20 and $50 \%$ glass substitution

mesh. However, the $\mathrm{SiO}_{2}$ content increased with molecular mesh sieve and glass substitution variations.

The greater the substitution of fine glass waste put into the mortar mixture, the more the amount of $\mathrm{SiO}_{2}$ compounds while the $\mathrm{CaO}$ decreases. This is because the refined glass waste contains a lot of $\mathrm{SiO}_{2}$ of $73.8 \%$. The reduction in $\mathrm{CaO}$ was due to being in the glass only $16.8 \%$. Therefore, glass should be limited to making mortar so that $\mathrm{SiO}_{2}$ in the mortar is adequately supplied. If it is excessive, it will reduce the ability of the cement to bind the mortar (Wibowo., 2017).

\subsubsection{X-Ray Diffraction (XRD) Characterization Results of Mortar}

XRD was used to identify the composition elements of each phase in the mortars based on the mineralogical identification. Thus, X-ray diffraction (XRD) characterization results allow a qualitative understanding of mortar type and function.

Figure 6 shows the diffractogram of mortar with 80 and 120 molecular sieves with 20 and $50 \%$ glass substitution. On these substitutions, the results show that the phases that dominate the diffraction peaks are Calcite $\left(\mathrm{CaCO}_{3}\right)$, Quartz $\left(\mathrm{SiO}_{2}\right)$, and Portlandite $\left(\mathrm{Ca}(\mathrm{OH})_{2}\right)$. These are the phases of compounds that greatly influence the strength of the compressive strength, density, absorption, and porosity.

In the 20\% substitution variation, the phase is dominated by the Calcite phase $\left(\mathrm{CaCO}_{3}\right)$ derived from $\mathrm{CaO}$, which reacts with $\mathrm{CO}_{2}$, followed by the Quartz phase $\left(\mathrm{SiO}_{2}\right)$ (Huseien et al., 2019). In the 50\% substitution variation, the Quartz $\left(\mathrm{SiO}_{2}\right)$ phase increased. This was due to the increase in the substitution of fine glass waste. Meanwhile, the Calcite $\left(\mathrm{CaCO}_{3}\right)$ phase decreases because, based on XRF data, $\mathrm{CaO}$ has decreased while $\mathrm{SiO}_{2}$ has increased. 


\section{TEKNIK, 42 (3), 2021, 314}

The peak height for each variation of $20 \%$ and $50 \%$ is different. At $20 \%$ substitution of glass waste, it was found that $2 \theta$ of $29.4175^{\circ}$ and 29.4092 indicated the Calcite phase $\left(\mathrm{CaCO}_{3}\right)$. Meanwhile, $50 \%$ substitution $2 \theta$ of $18.1027^{\circ}$ and $29.4152^{\circ}$ indicated the peak of the Portlandite $\left(\mathrm{Ca}(\mathrm{OH})_{2}\right)$ phase. This phase is formed because there is much $\mathrm{SiO}_{2}$ content. Excessive $\mathrm{SiO}_{2}$ content will bind to free $\mathrm{CaO}$ and form $\mathrm{Ca}(\mathrm{OH})_{2}$. $\left(\mathrm{Ca}(\mathrm{OH})_{2}\right)$ comes from $\mathrm{CaO}$, which reacts with water and forms a bond with Calcium Silicate Hydrate (CSH), the most important compound in cement formation (Tamanna et al., 2013).

\section{Conclusions}

Glass waste can be used as a substitute for sand because it contains $\mathrm{SiO}_{2}$ compounds of $73.8 \% . \mathrm{SiO}_{2}$ compounds can increase the compressive strength significantly but with the right composition by $20 \%$. The optimal results were obtained by both adding $20 \%$ fine glass waste substitution variation and soaking for 21 days with a molecular sieve of 120 mesh, for compressive strength of $13.58 \mathrm{MPa}$, the density of $2.8 \pm 0.8 \mathrm{~g} / \mathrm{cm}^{3}$, absorption of $2.83 \pm 0.0009 \%$, and porosity of $4.40 \pm 0.001 \%$. In this study, adding fine glass waste to mortar will result in the formation of phases such as Calcite $\left(\mathrm{CaCO}_{3}\right)$, Quartz $\left(\mathrm{SiO}_{2}\right)$, and Portlandite $\left(\mathrm{Ca}(\mathrm{OH})_{2}\right)$. These phases are needed in the cement hydration process.

\section{Acknowledgments}

The authors sincerely acknowledge sincere gratitude towards BPTM-LIPI and all team members who supported the study.

\section{Authors' contributions}

Suharto (S), Muhammad Amin (MA), Muhammad Al Muttaqii (MAM) were the main contributors. S and MA tested the samples and interpreted data. MAM collected the data, other information and drafted the article. Roniyus Marjunus (RM), Nuzullia Fitri (NF), Suhartono (SH) are member contributors. RM, NF, SH conducted major reviews, edits and added the analysis.

\section{References}

Amin, M. dan Suharto. (2017). The Producing of Environmental Friendly Geopolymer Cement With Raw Material of Basalt Minerals to Accomplish Welfare Lampung. Jurnal Kelitbangan, 5(1), 36-38.

ASTM D-2216. (1999). Standard Method for Laboratory Determination of Moisture Content of Soil. West Conshohocken, PA: American Society for Testing and Materials (ASTM) International.
Bentchikou, M., Bouriaha, S., Hamdanea, N., Debiebb, F., dan Boukendakdji, O. (2017). Comparative Study of the Properties of Mortars with Recycled Glass Assessing the Feasibility of Using the Heat Demand-Outd. International Conference on Materials and Energy 2015, ICOME 15, 19-22 May 2015, Tetouan, Morocco and the International Conference on Materials and Energy 2016, ICOME 16, 17-20 May 2016, La Rochelle, France. 139, 499-504.

Choi, S.Y., Choi, Y.S., dan Yang, E.I. (2018). Characteristics of Volume Change and Heavy Metal Leaching in Mortar Specimens Recycled Heavyweight Waste Glass as Fine Aggregate. Construction and Building Materials, 165, 424433.

Hambali, M., Lesmania, I., dan Midkasna, A. (2013). Pengaruh Komposisi Kimia Bahan Penyusun Paving Block terhadap Kuat Tekan dan Daya Serap Airnya. Jurnal Teknik Kimia, 19 (4), 14-21.

Huerta, E., Corona, J.E., Oliva, A.I., Aviles, F., dan Ganzalez-Hernandez, J. (2010). Universal Testing Machine for Mechanical Properties ff Thin Materials. Revista Mexicana De Fisica, 56 (4). 317-322.

Huseien, G.F., Hamzah, H.K., Sam, A.R.M., Khalid, N.H.A., Shah, K.W., Deogrescu, D.P., dan Mirza, J. (20190. Alkali-Activated Mortars Blended with Glass Bottle Waste Nano Powder: Environmental Benefit and Sustainability. Journal of Cleaner Production, . 243, 2-3.

Jesus, S., Maia, C., Farinha, C.B., Brito, J., dan Veiga, R. (2019). Rendering Mortars with Incorporation of Very Fine Aggregates from Construction and Demolition Waste. Construction and Building Materials, 229, 1-2.

Joni, I.M., Vanitha, M., Fanatarani, C., dan Faisal, F. (2019). Dispersion of Amorphous Silica Nanoparticles Via Beads Millig Process and Their Particle Size Analysis, Hydrophobicity and AntiBacterial Activity. Advanced Powder Thecnology.

Letelier, V., Henriquez-Jara, B.I., Manosalva, M., dan Moriconi, G. (2019). Combined Use of Waste Concrete and Glass as A Replacement for Mortar Raw Materials. Waste Management, 94, 107-108.

Olofinnade, O., Ede, A., Ndambuki, J., Omole, D., Jolayemi, K., Oyeyemi, K., Ajao, A., dan Ukoh, A. (2015). Sustainable Utilization of Crushed Waste Glass as Sand Replacement for Production of Eco-Friendly Interlocking Paving Stone. Materials Science and Engineering, 1-5.

Rahim, N.L., Amat, R.C., Ibrahim, N.M., Salehudin, S., Mohammed, S.A., dan Rahim, A.M. (2015). Utilization of Recycled Glass Waste as Partial Replacement of Fine Aggregate in Concrete 


\section{TEKNIK, 42 (3), 2021, 315}

Production. Materials Science Forum. 803, 1620.

Ramadani, Kurnia. (2018). Sintesis dan Karakterisasi Silika Gel dari Limbah Kaca Untuk Menurunkan Kesadahan Air. Jurnal Saintifik, 1(1)

SNI. 03-1968-1990. Metode Pengujian Tentang Analisis Saringan Agregat Halus dan Kasar. Jakarta.: Badan Standar Nasional.

SNI. 03-6825-2002. Metode Pengujian Kekuatan Tekan Mortar Semen Portland Untuk Pekerjaan Sipil Jakarta:: Badan Standar Nasional.

SNI S-04-1989-F. Spesifikasi Bahan Bangunan Bagian A (Termasuk Air). Jakarta : Badan Standar Nasional..
Tamanna, N., Sutan, N. M. Le, T. C., dan yakub, I. (2013). Utilization of Waste Glass in Concrete. Conference Paper. 6th International Engineering Conference, Energy and Environment (ENCON 2013)

Walczak, P., Malolepszy, J., Reben, M., Szymanski, P., dan KarolRzepa. (2015). Utilization of Waste Glass in Autoclaved Aerated Concrete. Procedia Engineering, 302-309.

Wibowo, A. (2017). Perbandingan Kuat Tekan dan Serapan Air pada Produk Mortar dengan Variasi Campuran Semen Artikel Ilmiah. Universitas Muhammadiyah Surakarta. 